Journal of Economics and Behavioral Studies

Vol. 2, No. 3, pp. 117-124, Mar 2011

\title{
Infrastructure in India: The Present Status and Its Constraints
}

\author{
Rudra P. Pradhan \\ Vinod Gupta School of Management, Indian Institute of Technology Kharagpur, India \\ rudrap@vgsom.iitkgp.ernet.in
}

\begin{abstract}
Provision of adequate infrastructure, in terms of both quantity and quality, is very essential for the rapid achievement of sustainable economic growth, both by increasing productivity and by providing amenities that enhance the quality of life. The objective of this paper is to investigate the role played by infrastructure, grouped under physical, social and financial, in determining economic development in India over the different time periods. An attempt is also made to find out the existence of intra-regional disparities, in terms of infrastructure, among the states of India. Using Factor analysis and regression analysis, the paper finds that infrastructure plays a significant role in determining the inter-state level of development in India during the past quarter century. The paper at the end discusses various challenges and opportunities for the infrastructure development in India and its link with sustainable economic growth.
\end{abstract}

\section{Keywords: Infrastructure, Development, India}

\section{Introduction}

The concept of sustainable development summarizes the challenges that the world is facing- to manage a global social and economic development that neither degrades the ecological systems nor exhausts natural resources (WCED, 1987). Infrastructure systems, hereafter referred to as infrasystems (Kaijser, 1994), play a key role in this problem area. The development of infrasystems has in many ways made everyday life easier (Jonsson, 2005). Infrastructure, in general, defines as a set of facilities through which goods and services are provided to the public. Its installations do not produce goods and services directly but essential inputs for all other socio-economic activities (Sanchez-Robles, 1998; Canning et al., 1994). It is referred as umbrella term for many activities and named as social overhead capital and economic overhead capital. WDR (1994) corresponds that infrastructure has a considerable significant positive impact on economic growth. It constitutes the wheels, if not the engines of economic development (Prakash, 2005; Karnik, 2003; Ghosh and De, 1998; WDR, 1994). Infrastructure has many interesting features (Pradhan, 2007; Mandele et al., 2006; Rao, 2006; Jonsson, 2005; Raghuram et al., 1999; Kaijser, 1994), which are as follows:

1. Infrastructure is a large-scale system and has strong technological dimension.

2. It facilitates socio-economic development of a country and its space acceleration.

3. Most of infrastructure is immovable physical components but it certainly deliveries some essential services to the economy.

4. Infrastructure lowers production cost and encourages direct productive activities.

5. Infrastructure brings managerial efficiency and hence, reduces technical inefficiencies and financial losses of an organization/ economy.

6. Infrastructure brings business opportunities and encourages international competitiveness in the economy.

7. It improves degree of specialization and comparative advantage in the economy.

8. It has large spillover effects (externality) and can affect production, consumption and distribution directly.

9. Its creation is both demand driven and supply driven.

10. Its creation is very complex, long gestation and involves large amount of expenditure.

11. On the social front, infrastructure generates employment and income and hence, alleviates poverty and unemployment.

12. It can ensure sustainable economic growth and quality of life in the economy. 


\section{Scope of Infrastructure}

Infrastructure is represented as a strong determinant for economic growth; both directly and indirectly. It plays a catalytic role in the process of development (Kapila and Kapila, 2002) and its services are essential to the commodity producing sectors of an economy. It affects the economic activity in two ways, viz., demand side and supply side. On the demand side, it opens up possibilities of investment by making available a number of necessary inputs and services, opening up the size of the market as well as increasing the supply elasticity and efficiency of factors of production. Supply side, on the other hand, gives emphasis on the development of infrastructure, which helps in mobilizing potential saving and channeling them into productive investment. Hence, it may be said that the SOC truly provides the infrastructure on which the superstructure of economic activities is built-up (Pradhan, 2006). WDR (1994) has already focused infrastructural development has a significant positive impact on economic growth. Infrastructure itself consists of different sectors and some of these sectors have direct impact on the workings of business enterprises and others are important for the societal point of view. Therefore, it needs to be developed on a concurrent basis. The relationship between infrastructure and economic development may be analyzed by focusing on its impact on the basic determinants of development particularly through its link with capital formation and technological change. The close link of factors, which determining the supply of capital with various items of infrastructure is quite obvious especially in the case of financial institutions. They are necessary both for mobilizing savings and providing capital for agricultural \& industrial development. Infrastructure is multidimensional in nature. Its role, besides economic dimension, in other developmental activities include alleviating rural poverty, improving standard of living, increasing rate of urbanization, generating employment and last but not the least is the impact of environment. Infrastructure's linkages to the environment are felt both through its effects on the quality of life and on economic productivity. The effects could be positive as well as negative, depending on the nature of each infrastructure development and what the alternatives are.

\section{Classification of Infrastructure}

Infrastructure is categorically grouped under two heads such as physical and social. Physical infrastructure directly affects production activities. It covers wide range of activities such as transportation (roads, railways, airways, water supply, etc.), energy (power generation, transmission and distribution), telecommunication, solid waste management, special economic zones (SEZs) and so forth. On the contrary, social infrastructure indirectly affects the system since its components have hardly any direct role in the productive activities. It generally covers education, health; human resource development, public distribution system, sanitation, sewerage, legal framework and so forth (see Figure 1).

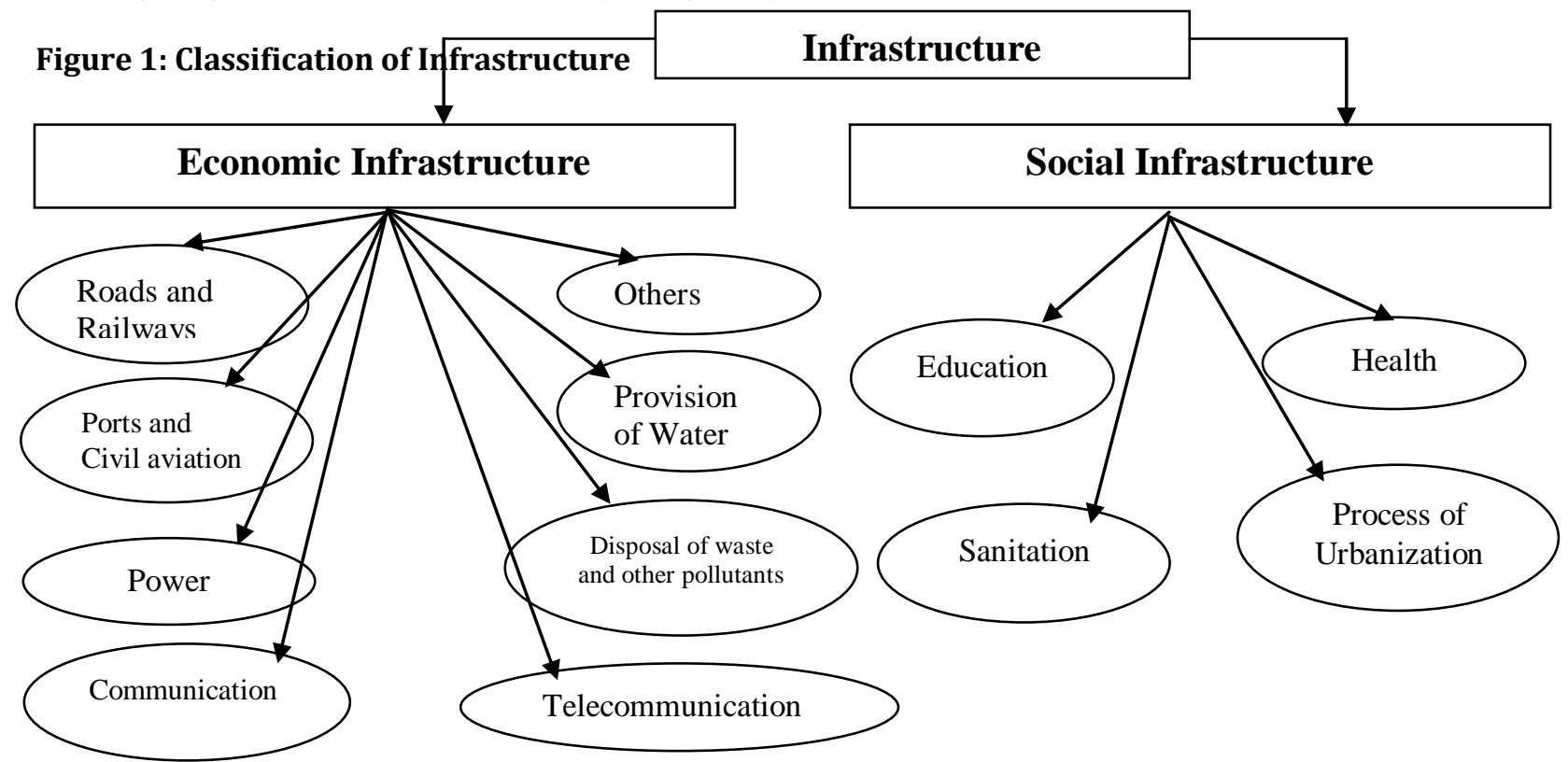

Source: Mandele, et al., 2006; Roy, 2006; Jonsson, 2005; Sengupta, 1998; Kaijser, 1994 
Infrastructure can also be classified as rural and urban, depending upon the nature of economic classification. Urban is usually applied to a spatial unit having certain specific characteristics, which differentiate it from a rural unit. It takes in the form of a town, city or metro, as against the rural unit. An area can be considered as urban, if it satisfies the following conditions: a minimum of 5000 inhabitants; at least $75 \%$ or more male working population engaged in non-agricultural activities; population density of at least 400 persons per sq. $\mathrm{km}$.; and having sufficient availability of socio-economic infrastructure like project colonies, railway colonies, university campus, important tourist centres, areas of intensive industrial development, etc. Urban economy usually faces serious challenges for its growth and management, particularly in the developing countries like India. Across the countries, the issues of urbanization manifest in the form of overcrowding, congestion, insufficient infrastructure, inadequate services like sanitation, drinking water, energy, transport, solid waste management, environmental degradation, etc. However, infrastructure covered under both groups are not only complementary to one other but also interdependent too in propelling both primary and secondary sectors of the economy (Khader, 1998).

\section{Status of Infrastructure in India}

Infrastructure is a multi-dimensional concept. Its status can be examined at the individual level and aggregate level. The paper highlights the status at the aggregate level (see Table 1) and specifically compares with other countries in the world. It is true that almost all the countries in the world have realized the role of infrastructure towards the development and given its due importance. For instance, in the first half of the 19th century, when Europe experienced the Industrial Revolution, the pioneers focused on building the base that would support further economic development.

Table 1: The Status of Infrastructure in India

\section{Current infrastructure status in India}

\begin{tabular}{|c|c|c|c|c|}
\hline Item & 2006-07 & 2007-08 & 2008-09 & $\begin{array}{c}\text { April- } \\
\text { Dec.2009 }\end{array}$ \\
\hline Power Capacity Addition (MW) & 6,853 & 9,263 & 3,454 & 6,375 \\
\hline Addition to Refinery Capacity- Petroleum & 5.1 & 16.5 & 29 & Nil \\
\hline Road Length Upgraded -NHAI (km). & 636 & 1,683 & 2,203 & $1,486^{*}$ \\
\hline Road Length Upgraded NIH (0) \& BRDB- km. & 1,686 & 1,897 & 2,226 & $1,294^{*}$ \\
\hline Road Works Completed under PMGSY (km) & 30,710 & 41,231 & 52,405 & 36,273 \\
\hline Route km RKMs electrified-Railways & 361 & 502 & 787 & \\
\hline Additional Locations with Computerized & 82 & 234 & 88 & $189^{*}$ \\
\hline New Lines (km)-Railways & 250 & 156 & 357 & \\
\hline Doubling of Lines (km)-Railways & 386 & 426 & 363 & \\
\hline Gauge Conversion (km)-Railways & 1,082 & 1,549 & 563 & \\
\hline Addition to Port Capacity (MTPA) & 48.5 & 27.3 & 42.7 & \\
\hline $\begin{array}{l}\text { Net Addition to Switch Capacity-Telecom } \\
\text { (000 lines) }\end{array}$ & 9,603 & 7,159 & 14,393 & $7,105^{*}$ \\
\hline
\end{tabular}

Source: Ministry of Power, Ministry of Petroleum \& Natural Gas, Ministry of Statistics and Programme Implementation (MoSPI), National Rural Roads Development Agency \& Ministry of Railways.* AprilNovember.

In USA, in the later half of the $19^{\text {th }}$ century, a lot of emphasis was placed on building infrastructural facilities for economic development. Similarly in China, a lot of emphasis was given on infrastructural development during the period of Deng Xiao Pang. However, the awareness on the importance of infrastructure in India came very late. During the British era, building infrastructure was essentially for the smooth functioning of their government. Infect, the scope of the infrastructure services was very limited to the extent that it served 
their own purpose. Even in the post independence era, infrastructural policies are by and large very lopsided. The country brought itself to a stage of blurred vision and has been a prisoner of its socialistic rhetoric. This kind of a lopsided policy making has resulted in lots of shortcomings in the Indian infrastructural sector. The few lacunas of India's infrastructure are as follows:

$>$ The availability of infrastructure in India is very small as compared to the county's need, especially in the fields of transportation, energy and telecommunication. They are also lack in quality.

$>$ There is an inappropriate mix of different infrastructural sectors. Infect, different components are also unsatisfactory.

$>$ The existing infrastructure is under-utilized and improperly used. Sometimes there is an inadequate demand due to failure in other sectors. The lack of proper co-ordination in the other sectors also contributes to the inadequate demand of infrastructure.

$>$ The existing infrastructure also lacks in quality and sometimes miss- utilized.

$>$ The private sector participation in the infrastructure demand is also very low in India.

$>$ The existing infrastructure is both under-utilized and improperly used. Sometimes, there is an inadequate demand due to failures in other sectors, or there is a lack of proper coordination in the other sectors in respect of their demands.

$>$ The last but not the least is the existence of large-scale inter-regional disparities in the infrastructural sector.

Although India has been struggling to keep up with the fast developing infrastructural demands of the businesses, it has shown some signs of progress. The pace at which the government is contracting new road contracts to private investors is phenomenal.

\section{The Constraints of Infrastructure}

Robust economic growth and a buoyant outlook are drawing attention to the status of India's infrastructure and its ability to support future growth especially in urban areas. The process of urbanization has gathered considerable momentum in recent years and this has put urban infrastructure and services under severe strain. India can only unleash its full growth potential and grow at 9 to 10 per cent p.a. provided it improves the infrastructure facilities. Financial issues for infrastructural projects are often cited as the key constraint to the availability of provisions in emerging economy like India (Pradhan, 2005). These are explained in two heads such as macroeconomic constraints and institutional constraints (See Figure 2).

\section{Macroeconomic Constraints}

\section{Nature of Savings}

Household savings is composed of both financial and physical savings. Financial savings in the household sector comprise savings in the form of currency, net deposits, shares and debentures, net claims on government, life insurance funds and PFs and pension funds. Savings in physical assets consist of net addition to physical assets of the household, comprising investment in construction, machinery and equipment and change in stocks. If as envisaged in Eleventh plan that the GDS will rise by 1 percent each year, which is over optimistic, the degree of financial intermediation required will have to be even higher. The tenor composition is a related issue for getting finance available for short term and long term, although steps have been taken by increasing pension and insurance penetration to help in mobilizing larger long term savings, but such attempts can materialize only in long run. So, in medium terms, additional access to external finance for infrastructure sector in form of foreign equity capital and long term debt finance would be necessary, more so if the share of the financial savings in GDP doesn't rise as envisaged. 
Figure 2: The Constraints of Infrastructure Finance

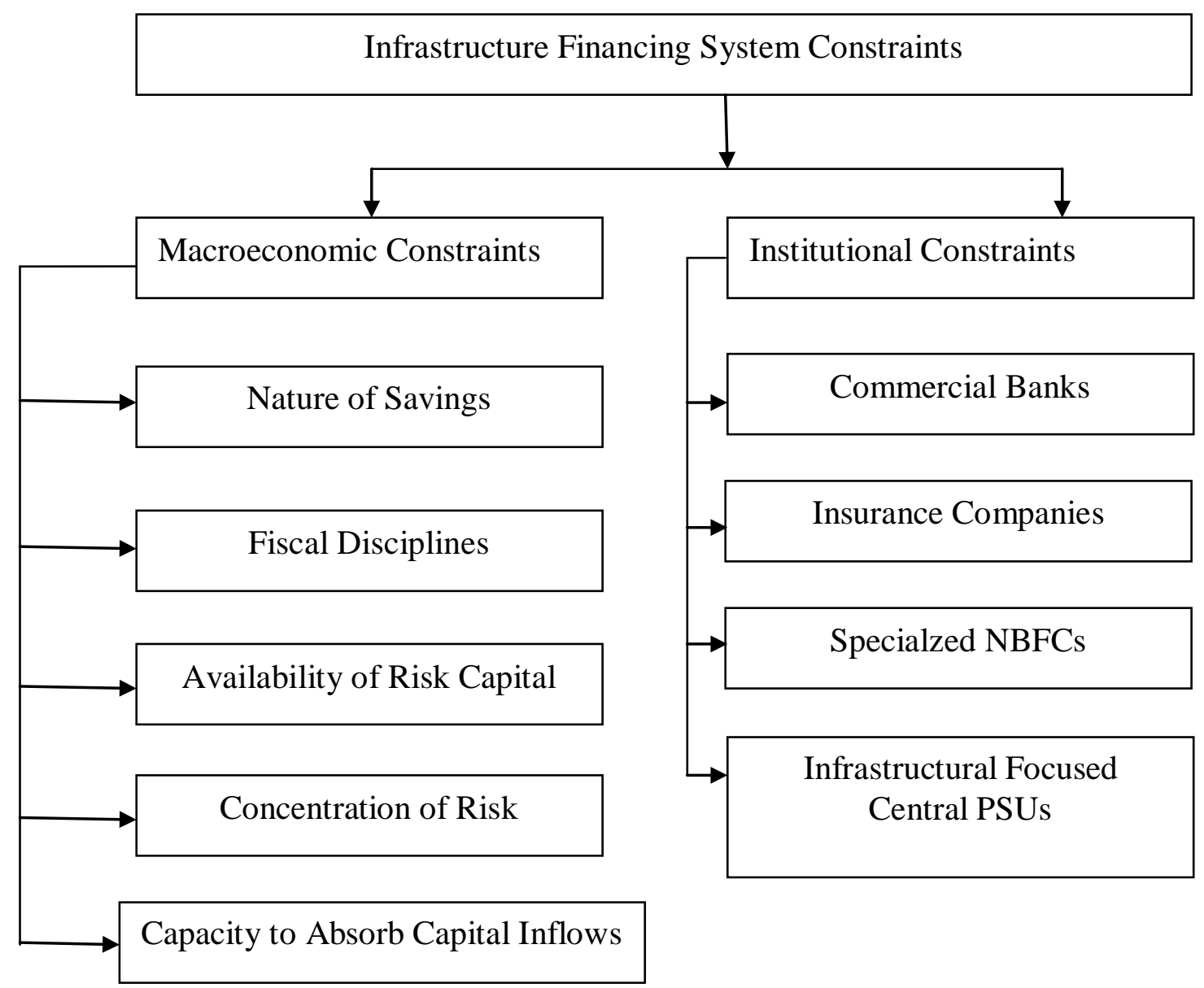

Source: The Report of the Committee on Infrastructure Financing

\section{Fiscal Discipline}

There will be limited scope for central and state governments to raise their support budgetary as well as guarantees - to infrastructure (as a share of GDP) in coming years within the constraints of the FRBM laws. So, governments can finance only a small part of the financing gap; then the predominant part of the gap has to be bridged by the private sector and PSUs. In this situation the government on one hand has to improve the efficiency of the limited spending of own limited budgetary resources for spending on infrastructure and on the other hand to encourage private companies and PSUs having cash surplus for leveraging, to access private financing to take up increasing share of burden for developing the country's infrastructure.

\section{Availability of Risk Capital}

Lack of availability of risk capital has remained one of key constraints to support debt raising and despite the fact that the domestic equity market is well developed adequate flow of equity capital in infrastructure sector has not been forthcoming, so, for infrastructure sector market for other forms of risk capital, such as mezzanine financing, subordinated debt and private equity, needs to be developed. 


\section{Concentration of Risk}

The projects with large investments have higher financial risk and have tended to get into few big financiers only. The existing single asset and single industry exposure norms make the challenge even bigger for Indian lenders which emphasize the need to improve the capacity to distribute the risk widely and efficiently and also to explore the possibility of making exceptions for infrastructure as regards exposure norms in certain cases.

\section{Capacity to Absorb Capital Inflows}

India having the large external debt capacity could borrow an additional $\$ 120$ billion in next five years maintaining its external debt to GDP ratio at current ratio of 15 percent which is considered sustainable. By using the one third of this capacity for financing infrastructure, India would cover 10 percent of infrastructure financing gap envisaged over the next five year period. Since, the infrastructure related debt is long-tenured; it also won't pose any threat to external viability. However, the ability of Indian economy to absorb various capital inflows poses challenge with relation to monetary management.

\section{Institutional Constraints}

\section{Commercial Banks}

Due to small saving, commercial banks have registered a high growth in their exposure to infrastructure (57 percent in CAGR) during $10^{\text {th }}$ Plan. When infrastructure spending is sought to be increasing, the banking system exposure to infrastructure would have to rise significantly as a percent of GDP, because of the impending constraints on government spending due to FRBM laws. The banking sector exposure norms and maturity mismatch may prevent banks meeting the challenge; also the other constraint for the public sector banks to increase their infrastructure financing portfolio is the overall capitalization.

\section{Insurance Companies}

Because of the regulatory restrictions, underdeveloped corporate bond markets and the absence of efficient credit risk transfer mechanisms (such as securitization, credit derivatives, credit insurance etc.) the insurance companies although being the eligible investors have invested limited amounts in private infrastructure development.

\section{Specialized NBFCs}

In the backdrop of diminishing role of development financial institutions, the role of NBFCs have been regularly growing although it is new entrant in infrastructure financing. Because NBFCs have focused business models based on their deep knowledge of, and appetite for, complex and long gestation projects in infrastructure sector and also are less likely to pose systemic risk, they are expected to play a more critical role in infrastructure financing. The inability of NBFCs to optimally utilize their capital and balance sheets through mechanisms like securitization, and their limited access to low cost financing option, are major constraints to growth prospects of NBFCs. And NBFCs are increasingly facing the exposure norm constraints in financing infrastructure even more than the commercial banks.

\section{Infrastructure Focused Central PSUs}

PSUs play significant role in infrastructural financing (accounting nearly 40 percent) and would have to continue in future also. Considering the fact that there is general shortage for equity/ risk capital for infrastructure projects in country several PSUs should adequately leverage the strength of their balance sheets to raise resources from market and invest large amount of idle cash they are holding. 
Table 2: Investment Requirement of Infrastructure Development in India

\begin{tabular}{|c|c|c|c|}
\hline Sectors & $\begin{array}{c}\text { Anticipated } \\
\text { Investment in } \\
\text { 10th FYP }(2002-2007)\end{array}$ & $\begin{array}{c}\text { Projected } \\
\text { Investment in } \\
\text { 11th FYP }(2007-2011)\end{array}$ & $\begin{array}{l}\text { Percentage } \\
\text { Change } \\
\text { (in \%) }\end{array}$ \\
\hline \multicolumn{4}{|c|}{ 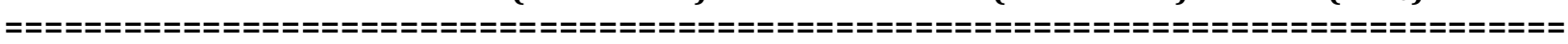 } \\
\hline Electricity & 70.5 & 150.4 & 111.3 \\
\hline Roads and bridges & 31.7 & 76.1 & 140.1 \\
\hline Telecom & 22.5 & 65.1 & 189.3 \\
\hline Railways & 20.3 & 62.2 & 206.4 \\
\hline Irrigation & 32.1 & 53.1 & 65.4 \\
\hline Water and sanitation & 15.6 & 48.6 & 211.5 \\
\hline Ports & 1.3 & 18 & 1284.6 \\
\hline Airports & 2.1 & 8.5 & 304.8 \\
\hline Storage & 2.3 & 5.5 & 139.1 \\
\hline Gas & 2.1 & 5.0 & 138.1 \\
\hline Total & 200.5 & 492.5 & 145.6 \\
\hline
\end{tabular}

Source: Planning Commission, Government of India

\section{The Future Perspective}

India's development largely depends on the availability of essential infrastructure, as it is low in quantity and quality. We, hence, need a serious thought and deploy resources to a rapid up-gradation of our infrastructure (Government of India, 2007; Mor and Sehrawat, 2006; Karnik, 2003). With the given pitfalls, which we have discussed, in the above, the following recommendations may be very essential to reach our goal.

> Government should give stress on sufficient availability of infrastructure in the economy both in terms of quantity and quality. There is also need to popularize this sector in the economy.

$>$ Massive dose of public investment must be required to rejuvenate the infrastructural sector (see Table 2).

$>$ A greater private sector participation in infrastructural development is essential not only due to the constraint of Government but also to improve the quality of services and the delivery system.

$>$ A structural reform in the infrastructure sector is required for promoting greater efficiency and viability by freeing them from excessive bureaucratic control and political inference.

$>$ Enabling policy changes related to withholding tax, rationalization of divided distribution tax and tax treatment of investment in ultra mega power plants and unlisted equity shares (GOI, 2007).

$>$ Integrate infrastructural sector with other sectors of the economy.

$>$ To induce foreign investments into infrastructure and steps required to utilize foreign exchange reserves to accelerate capacity expansion of infrastructure projects in India.

To conclude, all the above recommendations have been to widen the scope of infrastructure. This helps improving productivity, qualities of life and ecological sustainability in the economy. In short, the above ideas address our peripheral economic and social problems of more urgent nature relating to our sustenance in a better way. 


\section{References}

Canning, D., Fay, M. and Perotti, R. (1994). "Infrastructure and Growth", in Baldassarri, M. Paganaetto, M. and Phelps, E. S. (ed.), International Differences in Growth Rates. New York: St. Martins Press.

Ghosh, B. and De, P. (1998). 'Role of Infrastructure in Regional Development: A Study over the Plan Period', Economic and Political Weekly, 33 (40): 3039-3048.

Government of India (2007). The Report of the Committee on Infrastructure Financing. Planning Commission, Government of India, New Delhi.

Jonsson, D. K. (2005). "The Nature of Infrasystem Services", Journal of Infrastructure Systems, 11 (1): 2-8.

Kaijser, A. (1994). I Fadrens Spar: Den Svenska Infrastructurkrurens Historika Unveckling Och Framtida Utmaningar. Carlson: Stockholm.

Kapila, R. and Kapila, U. (2002). India's Economy in the $21^{\text {st }}$ Century, New Delhi: Academic Publications.

Karnik, K. (2003). 'Criticality of Soft Infrastructure', The Economic Times, 6 November.

Khader, S. A. (1998). 'Productivity in Infrastructure', Yojana, 42 (1): 13-18.

Mandele, M. V., Walker, W. and Bexelius, S. (2006). "Policy Development for Infrastructure Networks: Concepts and Ideas", Journal of Infrastructure Systems, 12 (2): 69-76.

Mor, N. and Sehrawat, S. (2006). Sources of Infrastructure Finance, Working Paper. Chennai: Institute for Financial Management and Research.

Pradhan, R. P. (2005). "Urban Infrastructure in India and Their Financing", Journal of Social Sciences and Humanities, 3 (2): 13-41.

Pradhan, R. P. (2006). "Rural Infrastructure is a Key to Rural Poverty: The Indian Experience", Journal of Infrastructure, 4 (2): 59-72.

Pradhan, R. P. (2007). "Social Infrastructure in India: The Present Scenario and Future Perspective", Journal of Applied Economics and Policy Analysis, 1 (1): 43-62.

Prakash, H. (2005). “Urban Infrastructure- A Glimpse”, Southern Economist, 44 (9): 26-30.

Raghuram, G., Jain, R. Sinha, S., Pangotra, P. and Morris, S. (1999). Infrastructure Development and Finance, New Delhi: Macnillan Publications.

Rao, S. M. (2006). "Financing Urban Infrastructure in India", The Management Account, 41(2): 146-153.

Sanchez-Robles, B. (1998). "Infrastructure Investment and Growth: Some Empirical Evidence" Contemporary Economic Policy, 16: 98-108.

Sengupta, J. K. (1998). "Infrastructure and Economic Growth", in New Growth Theory- An Applied Perspective, PP. 209-218. United Kingdom: Elgar Publications.

WCED (1987). World Commission on Environment and Development (WCED), Oxford: Oxford University Press.

WDR (1994). World Development Report (WDR), The World Bank, Washington: Oxford University Press. 